International Journal of English Literature and Social Sciences
Vol-7, Issue-1; Jan-Feb, 2022
Journal Home Page Available: https://ijels.com/
Journal DOI: $10.22161 /$ ijels

Peer-Reviewed Journal

\title{
Transformation of the Western Gaze: A Postcolonial Analysis of Rudyard Kipling and John Davies' 'Kim'
}

\author{
Vishal S Thomas
}

Department of English Literature, Christ University, India

Email: vishalthomas2000@gmail.com

Received: 03 Dec 2021; Received in revised form: 12 Jan 2022; Accepted: 20 Jan 2022; Available online: 23 Jan 2022

(C)2022 The Author(s). Published by Infogain Publication. This is an open access article under the CC BY license

(https://creativecommons.org/licenses/by/4.0/).

\begin{abstract}
Construction of the Orient by the 'West' in narrative imaginations involves numerous problematic distortions in its depictions. This 'construction' follows the view of the Orient through the 'western gaze', which establishes and further thrives on binaries and hegemonies between the Occident and the Orient, mainly through the processes of 'exoticisation' and 'othering'. Kipling's 'Kim' and Davies' adaptation of the book can be seen to employ the 'western gaze' in different manners according to their respective affiliations with the colonial and postcolonial periods. This paper seeks to trace the transformation of this western gaze from the colonial to the Postcolonial period; from a book to a film, and explores how it brings about numerous consequences of the colonial period to the modern contemporary world.
\end{abstract}

Keywords-Colonizer-Colonized Relationship, Kim, Kipling, Orient, Hegemony, Postcolonial Studies, Western Gaze.

\section{INTRODUCTION}

Postcolonial studies explore the subsequence of the colonial era, recounting its legacy in terms of the oppressive imperialism featured by the 'colonisers'. 'Gaze' as a concept, in reference to Mulvey's ideas, elaborates the patronizing construction of the Orient, as perceived by the Occident to retain the hegemony. Hence, the persistence of gaze ideates a reconstruction of colonial values in contemporary times which inspires the potential in critical research. Films and books are believed to be the reflection of society, which as an extension demands the viewer to generate meaning out of it (Yoshimoto, 1991). This selectively represented, "received" perception of ideas as put forth by the author, rather than the direct consumption of it as a personal experience, creates a narrative capable of announcing deep impact upon its viewer, influencing biases, opinions, understandings, political mindsets, social conduct etc (Mendes, 2010, p. 472). India, as a nation housing millions of people, remains a victim of stereotypical and problematic representations due to imperialist oversights.

Rudyard Kipling's novel, 'Kim' and John Davies' movie, based on the novel with the same name form the two primary texts of the paper. Kipling's 'Kim', a novel published in 1901 during the British Raj, was one of his final and most acclaimed works. Set against the backdrop of the political confrontation of 'The Great Game', it describes the story of an Irish Orphan named Kim, becoming a devoted disciple of a Tibetan lama (Buddhist monk), while learning espionage from the British secret service. The book explores the varied Indian culture, traditions, diverse exotica of the streets, populace, lifestyle, by incorporating a certain 'nostalgic aesthetic'(Baker, 2009).

John Davies, born in 1934 in the United Kingdom, is the director of the movie adaption of Kipling's book 'Kim' which was released in 1984 with the same name. While the screenplay of the movie reflects Kipling's original, it reimagines certain additions to the plot with the 
denouement undergoing a considerable shift from the original text. A number of snipes are taken at the British imperialist regime, which apparently was solely brewed for the sake of political correctness.

This paper titled Transformation of the Western Gaze: A Postcolonial Analysis of Rudyard Kipling and John Davies' 'Kim' uses the theoretical framework provided by Postcolonial studies and Visual culture studies along with a comparative analysis to understand the construction of the Orient according to the 'Western Gaze' employed by Kipling and Davies in their works. Firstly, this construction is explored by carrying out a comparative analysis of Kipling's Kim and the film adaptation by Davies. The focus remains on individual representations of the Orient, the retention and divergences employed while adapting the film and finally, the 'seen-unseen' aspects, specifically the omissions, meaning distortions and enunciation politics including aspects such as visual indications, intonations and local references in representations of the Orient. This will be done by exploring the characters of 'Kim' and 'Colonel Creighton' in the context of the colonial period and how their characters change in the film adaptation released in the postcolonial era. Portrayals of the settings of Lahore, Banares and Shimla etc are also scrutinized to view the 'exoticized' perspective put forth by the authors in their respective works.

Secondly, the translational nuances that the text undergoes while adapting a visual form is critiqued in order to define the similar and dissimilar imperialist tropes which are employed along with their dynamic flux through time and medium. This is achieved by exploring the contrasting factors like distinctive representation of the colonisercolonised relationships in the two texts, the authenticity of representation including Kipling's Indian background and Davies' representation of the locals through western actors etc. Columpar in his article quotes Rey Chow, "modernity is specifically grounded in visuality" (Columpar, 2002, p. 27) while Berger also says " Seeing comes before words" (Berger, 1972, p. 7), both of which indicate how visuality, as compared to textual depiction, impacts the audiences' reception.

Drawing from the inferences of the first two observations, a concluding deduction will be made regarding the retention and restructuring of the imperialist gaze in the contemporary postcolonial era, especially through art and media while keeping Mulvey idea of " complete disavowal of castration by a fetish object or turning the represented figure itself into a fetish so that it becomes reassuring rather than dangerous" (Mulvey, 2009, p. 840) in mind. Hence, the condescension and 'othering' of the western gaze will be scrutinized through the comparative analysis of the two texts to highlight the imperialist construction of the Orient by the Occident and its transformation through time and mediums.

The existing research focuses majorly on the colonizercolonized relationship of the texts, specifically the identity crisis of the character Kim, foreign relations of countries and colonial politics of the past while employing a postcolonial perspective, as it completely overlooks the role and retention of the imperial gaze in the contemporary world, transformed through time. The paper aims to address this gap by intricately bridging the gap between 'gaze' and 'colonial imperialism', by exploring its transformation through time and medium. Furthermore, the paper opens up a wide array of elements to be further researched and aims to unravel the potential of postcolonial studies in contemporary times. It promotes cultural analysis through time and space, offers distinctions of and explorations into colonialist and contemporary literary traditions and also researches the 'western gaze' upon the oriental cultures with reference to literature, films, art etc through profound cross-cultural and literary analysis.

There persists an imperial 'othering', as an influence and aftermath of the British colonial rule in India, transforming through time and medium in manners of the 'Western gaze', which effectively informs the Occidental construction of the Orient in terms of medium translation, aesthetic codes, textual and visual representation, traditions and institutions in Kipling and Davies' composition of 'Kim'

\section{KIM AND THE CONSTRUCTION OF THE ORIENT}

Kim, as one of the final and most acclaimed works of Rudyard Kipling, has gained him a considerable position in the literary field. The controversial piece recounts the story of Kimball O'Hara, regularly referred to as 'Kim' in the book, in a spiritual and cultural journey through the Indian subcontinent both as an official of the British Secret Service and as an apostle to a Tibetan lama. As the story unfolds, one finds themselves a witness to numerous problems, biases, misrepresentations and an imperialist construction of the Orient and its associated cultures in Kipling's opinionated tale. John Davies, in 1894 directed a film as an adaptation of the book, which, unlike Kipling's work, was created in the postcolonial era. Hence, it defined the ideas and representations of the book with respect to the 'developed' outlook of the people regarding the colonial rule. 
The pro-imperialist depiction of 1890 s British India as narrated by Kipling and its visual manifestation through Davies' work, can be deeply analysed on the basis of various distinctive aspects such as settings, characters, cultural attributes, language and even religion. Furthermore, questions regarding the colonizer-colonized relationship can be explained using instances from the text in reference to theorists like Spivak, Bhabha and Said. Lastly, the intricacies in medium translation can be addressed in terms of nuances in depiction, plot, dialogues etc.

To understand the construction of the Orient according to the occidental perception we can analyse certain features and depictions within the book and the film which explicate the oppressive and stereotypical representation.

\subsection{Settings and Background Representation}

Firstly, the setting of the book plays a major role in describing Kipling's thorough exposure to the Indian regions and culture. The political conflict between Russia and Britain forms the backdrop of the book which considerably influences the course of the plot. Known as the 'Great Game', this conflict catches India in the middle of its Anglo-Russian crossfire, which depicts India as a primitive territorial involvement in the power struggle of the colonisers. Various place settings like Lahore, Umballa, Delhi, Patiala, Kalka, Shimla, Quetta, Karachi, Bombay, Banares, Saharanpur, Mussoorie, Kinnaur and even ambiguous locations like the Kulu Woman's house are represented in the book. This diverse recounting of regions and their associated cultures, along with the aspects of mystery and peculiarity it holds in reference with the Western experience, is used to exoticize the oriental construction and build it as an experience rather than a lifestyle (Yin, 2005).

Davies' 'Kim', attempts to strictly follow Kipling's footsteps in encompassing India's cultural and geographic diversity as the shots and settings of the film are premised on authentic locations within India. With mild curtailment in the extent of diversity in Kipling's depictions, Davies' represents locations like Banares, Shimla, Delhi, Patiala and Bombay in body, which although increases the reliability of narration, creates a masked sense of authenticity and familiarity. A brief introduction scene is appointed to all the new locations ahead of plot progressions like congested streets and flowing waters of Banaras (Davies, 1984, 00:13:34- 00:14:54), the towering mountains of Shimla and Mussoorie (Davies, 1984, 01:26:45- 01:28:01) and the bustling handicraft shops and grand buildings of Bombay (Davies, 1984, 01:52:5501:53:59), which are depicted by Davies in his film, assuming the position of an insider who introduces the peculiar lands of India to the unbeknownst audience, contributing to his 'intimacy' with the exotic land.

\subsection{Use of Language in Kipling and Davies' 'Kim'}

Secondly, the language of the book and its adaptation in the film greatly connotes the imperialist 'gaze' of the Western identities while depicting the Orient. Kipling delineates the linguistic hierarchy suggesting the supremacy of English over other Indic languages prevalent throughout the novel, like Urdu, Hindi, Punjabi. With an evident inclination towards the pro-imperialist ideas, we can notice many instances that suggest a justification to the British colonisation, like when the lama is unable to communicate to the Punjabi policeman near Lahore Museum due to linguistic complications, Kim steps in to bridge the gap (Kipling, 1978), which may be interpreted as the incompetence of the Indians to communicate among themselves without the assistance of the British.

Another indication of the suggested superiority of English in terms of both cultural and linguistic elements, it can be noticed how Kim, usually 'thinks' in Hindi (Kipling, 1978, p. 123), but when Lurgan attempts to trick him, he switches to English (Baker, 1978) in the lines- "[H]is mind leaped up from a darkness that was swallowing it and took refuge in - the multiplication-table in English" (Kipling, 1978, p. 218). The aforementioned observation can be noticed in numerous stages in the book, that when Kim is driven by emotions like anger, fear and joy, he thinks like an Oriental in Hindi, while rationalising and constructive thinking is done as a Westerner, in English (Baker, 2009).

Frantz Fanon in his book "Black Skins, White masks" talks about the interrelation of racialized subjectivity and language, as the adoption of mutual language among the colonizer and colonized being the "eliminator of other expressive forms" and hence this partaking reflects and promotes the hegemonic culture and oppression through language (Fanon, 1967, p. 30-36). Davies' Kim records such fluctuations in conventional, unblended languages and indicates the variety of spoken words and their dialects through a series of intonations, pronunciations, word assembly, grammar etc.

In Kipling's Kim, we see the line "I came by Kulu- from beyond the Kailas- but what know you? From the hills where" he sighed- "the air and water are fresh and cool." "Aha! Khitai" (Chinaman), said Abdullah proudly." (Kim, 1978 , p. 6), which greatly defines the blended forms of the English language with varying grammatical practices, foreign words like "Khitai", local forms of expression like 'Aha' etc which define a mutual language among the coloniser and colonized in general. The adoption of such results in bridging the gap between cultures like Punjabi and Tibetan with the colonizer's product. 
Conventionalization of their usage contributes to the oppressive gaze of the imperialist colonists.

\subsection{Role of Religion in Colonial Hierarchy}

Thirdly, conventionally unifying aspects like religion play a great role in establishing division among the people, majorly in terms of highlighting the coloniser's superiority. Said, in his book Orientalism, elaborates upon a 'binary social relation' that can be defined as the mutual dependence of the Orient and Occident for either's existence and the construction of the former based on its lack of 'Western values' (Said, 1979). Kipling's Kim subtly features the age-old Christianity-Islam feud, in numerous ways. Initially, the lines "All Mussalmans fell off Zam-Zammah long ago" (Kipling, 1978, p. 5) and "the Hindus fell off Zam-Zammah too" (Kipling, 1978, p. 5), Kim patronizes the Muslim and Hindu kids for their past and background as a member of the colonizer's white race, popularly known for their Christian agendas. This indicates how the lines become blurred between cultures, i.e in this case Hindus and Muslims and classes through homogenisation while indicating its stark binary of English values and beliefs, powerfully establishing the colonial hierarchy. Another instance of this can be the general contrast in Kim's background and atmosphere between his initial stages among people of Oriental religions as a delinquent panhandler and his time spent in St Xaviers as part of the elite English- cultured crowd.

Davies' 'Kim' however, recollects additional indicators of cultural and religious hegemony, by many aspects of its character portrayal. The lama, among other Indian characters, for instance, has a greatly submissive pose, of a bowing head, folded hands, lowered gaze etc in front of the English 'Sahibs', be it when he talks to Reverend Arthur Bennett (Davies, 1984, 00:27:26- 00:31:17), during his encounter with the Russian men ( Davies, 1984, 01:59:47- 02:03:38) or other such engagements with the English men, however, he maintains an upright posture, demanding respect on the basis of his religious background when he engages with a fellow Indian like initially greeting Mahbub Ali (Davies, 1984, 00:18:56- 00:19:05), the horseman (Davies, 1984, 00:45:01- 00:45:55) etc.

\subsection{Characters and their Representations}

Fourthly, the characters of the narratives follow and depict the hegemonic system established during colonial rule. Gayatri Spivak in her work, 'Can the Subaltern Speak', through the example of 'Sati,' in her lines "White men are saving brown women from brown men" (2009) describes how the homogenisation of the subaltern and further epistemic violence paves the way for the exploitative domination imposed upon the subaltern, specifically through colonisation. In Bhabha's theory of hybridity, he introduces the concepts of mockery and mimicry as "a desire to create other people that experience reformation and can be known as different person, nearly the same, but not quite" (Bhabha, 2012, p. 86). Considering the two theories of subalternity and hybridity we see many instances throughout the texts which indicate the imposed superiority of the West. For instance, the first chapter of Kipling's Kim unfolds with his caretaker insisting Kim wear European attires in the lines "The woman who looked after him insisted with tears that he should wear European clothes" (Kipling, 1978, p. 4). This act of preferring Western values and ideas over the local becomes a liminal act of mimicry as Bhabha defines, of the superior West. The subaltern class of Kim seeks to deserve respect and authority by meaning to mimic the Occidental values, through attires and culture in this instance, accepting their inferiority of "Hindu or Mohammedan garb" (Kipling, 1978, p. 4) or the "complete suit of Hindu kit, costume of a low-caste boy" (5) that the colonial rule imposes on local 'savages'.

In many ways, Kim becomes the physical embodiment of Bhabha's 'Third Space', as mentioned in his theory of hybridity. He becomes the middle ground for the two cultures undergoing a great Identity crisis both in the context of the narrative and as a character. For instance, in Kipling's chapter 6, it can be noticed that when Kim hails the sweeper to fetch the letter-writer (Kipling 1978), his initial look of a 'white boy' seems like the colonizer's indicative which inspires an apprehensive "insolence" (Kipling, 1978, p. 8) on his behalf. Although Kim subsequently resorts to profanity in his local language, the sweeper is inclined to abide by his command because of a sense of belongingness that is invoked. So we see how the third space records the retention of identities of both the coloniser and the colonized, and the subaltern identity fuses towards the colonizer's identity. So although many problems seem to arise, one can notice how by establishing close ties between the various characters, the author Rudyard Kipling asserts a mutually positive and favourable relationship between the colonizer and the colonized. Furthermore, a character analysis of Kim and Colonel Creighton in reference to their colonial and postcolonial representation in Kipling's book and Davies' film respectively can assist the dissection of the imperial construction of the orient through time.

\subsection{1 ' $\mathrm{Kim}$ '}

Kimball O'Hara is an orphan boy brought up in the 'exotic' land of India and is often described by his deceptive charm. The character can be summed as the cultural hybridity of the Indian savage and the English civilizer. There persists a great identity crisis that Kim 
undergoes throughout the book, which is evident in numerous places.

Starting from his contradicting racio-cultural background of a 'white' boy brought up within the Indian culture. While this may be considered synonymous with Kipling's past, his opinions and biases are seen to bleed into Kimball, as the protagonist. While initially "Kim found it easier to slip into Hindu or Mohammedan garb" ( Kipling, 1978 , p. 4) and preferred the local culture rather than the colonizer's way of life, his experience in St Xavier's School changed this desire to associate oneself with the natives and embrace the title of 'Sahib' ( Baker, 2009), as he was heavily discriminated during his time in the academy as the elite English-cultured crowd at the school "looks down on boys who 'go native altogether" (Kipling, 1978, p. 99). The conclusive standing of Kim suggests how his "white blood" supersedes his cultural conditioning, which indicates Kipling's strong inclination towards the genetic difference between races. (Baker, 2009).

Davies' postcolonial recollection of the novel, however, culminates with a greatly different ending to the narrative, which presents Kim attaining enlightenment along with lama at the River of the Arrows (Davies, 1984, 02:27:0002:29:07). Almost epiphanic in nature, the realisation of futile superiority of English ideals and Western colonial hegemony, although not outcome-explicit, resolves Kim's identity crisis. Another factor which Davies uses to diverge from Kipling's text, is the dimming of Kim's utter invulnerability to superstitions and illusions along with his non-religious outlook over life at instances like a brief conversational inquiry about religion after lama crosses the rivulet without killing the snake (Davies, 1984 01:12:0601:14:58), final enlightenment about spiritual beings in his line “..then why did he made us unequal?" (Davies, 1984, 02:27:05- 02:27:07). These manipulations in the original narrative indicate how Davies follows the postcolonial ideas of respecting the heritage and cultural value of the 'colonised', by not discarding or rejecting it altogether. Using the concept of protagonist bias he seems to withdraw the colonial hegemonic power of 'knowledge' from the colonizers and by taking snipes at western values such as " dictator Xavier" (Davies, 1984, 00:42:34), "disbelieved English lie" (Davies, 1984, 01:00:0501:00:07).

\subsection{2 'Colonel Creighton'}

Creighton on the other hand holds lesser and more direct contributions to the imperialist rule of British colonies in India. While Kipling considered Colonel Creighton, a man of well standing and wisdom, Davies adds a tinge of oppressive characteristics to Creighton in the film adaptation. Kipling presents Creighton as a man capable of moulding a street urchin and a delinquent into a responsible and important ally to the British cause. He is presented as a well behaved, conscientious British official whose role is to appoint and recruit trainees and agents from beyond the frontier, which ultimately changes Kim's life and plays a passive role in his enlightenment. Davies, on the other hand, presents Julian Glover playing Colonel Creighton in a very different light. The character of Creighton depicts a rashness absent in Kipling's description, clearly indicating the heinous and immoral nature of the colonizers. He showed to be very harsh and egotistical with his engagements with locals, for instance, he posits his position in the colonial hierarchy, as a basis of his impolite bluntness when enquiring about Kim disappearance from St. Xaviers, from Mahbub Ali in his dialogue "The boy has disappeared to his filthy roots" (Davies, 1984, 00:49:08)

An overall view of the narrative can indicate many aspects that contribute in the transformation of the imperial gaze from Kipling's colonial era to Davies' postcolonial outlook. Firstly, one can focus upon the seen-unseen aspects of the narrative. One can notice how the plethora of various races, cultures, identities etc have been represented in the narrative, with proper care and welldescribed backgrounds. The unseen aspect however remains the lack of economic and social mobility of these groups. For instance, how the lack of Indian officials and representatives in the British regiment becomes the establishing factor of an irreversible hierarchy set due to the western and colonial rule. Another intricacy to be focused upon is that despite Kim's poor background and tender age, Kim holds the power to attain a secure future with a well-yielding profession due to his "white blood" (Bandopadhayay, 2019). Through Kipling's biases and opinions, the story recounts Indian and colonised characters like Mahbub Ali to have a very contained flexibility awarded to them, irrespective of their capabilities and competence (Raimbault, 2016).

Secondly, considering the film adaptation one can see numerous omissions, meaning distortions and enunciation politics including aspects such as visual indications, intonations and local references in representations of the Orient. It can be noticed that Davies changes certain portions of the plot like the ending where Kim is granted enlightenment especially regarding the ideal social structure (Davies, 1984, 02:27:00- 02:29:07), character introduction of Mahbub Ali with a flashback (Davies, 1984, 00:26:39-00:27:21) rather than direct addition to the running plot, complete omission of the background story of side characters like the Old veteran and his son etc. Local references like Jamuns are used in the Kulu 
woman's processional abode (Davies, 1984, 00:47:33) to indicate Indian meanings of desire and sensuality.

\section{FROM TEXT TO FILM}

\subsection{Homogenisation and stereotypes}

To comprehensively understand the transformation of the imperial gaze, one needs to compare the aforementioned oppressive representations and imperialist construction of the Orient in Kipling's work to the translational nuances that occurred during the adaptation of the narrative by Davies in his film. Firstly, one can notice how Kipling's work emerges as an insider's perspective recounting India's exoticity in all its glory. Gayatri Spivak, in her work, 'Can the Subalterns speak?' talks about a certain homogenisation of the subaltern. The epistemic violence made by the colonizers is due to such a homogenisation of the 'colonized', as the mere 'absence of that knowledge'(Columpar, 2002, p. 39). This defining point unifies the varied west into the absence of the western values- as Said describes such binaries to constitute the process of Orientalism (Ahmad, 1992). This process of homogenization gives rise to the employment of stereotypes.

Davies in his work resorts to numerous stereotypes, much more than Kipling. In order to further 'exoticize' his real locations, he adds over the top use of traditional clothing like all children wearing Taqiyah to depict their belief in Islam (Davies, 1984, 00:03:25), and Hindu children having a 'puja sindoor' on their foreheads to depict their religion (Davies, 1984, 00:07:09). Another example of such use of stereotypes is the 'poverty-stricken dark Indian' trope, which follows throughout the film to highlight the class and race difference that sets the British upon a pedestal, as a saviour of the 'savages' (Aljohani, 2017). This outward appearance, as an extension, contributes to assigning the 'uneducated/ illiterate' status to the Indian, who lack rational thinking and are driven by pure emotion. The portrayal of Jamuns in the Kulu woman's abode is also evocative of a sense of sultry, sensuality being associated with her, as popular local indicators and symbols preach.

Yet another form of imperial construction of the orient may include the lack of authenticity in character representation in Davies' film. John Davies hires English actors like Peter O'Toole, Bryan Brown and John Rhys Davies to depict local Indian characters like Lama, Mahbub Ali and Babu. Such a shoddy representation laced the film and led to a number of controversies. Such an act makes a statement that 'colonizers better understand the needs and thoughts of a colonized than the colonized itself', suggesting how the British actors were better alternatives for important roles, as compared to the possible authentic representation by Indian actors.

\subsection{Colonizer-Colonized Relationships in Kipling and Davies' Kim}

The Colonizer- Colonized relationship depicted in the narrative becomes the fundamental point of debate. The distinctive line between the colonizer and the colonized is deeply blurred, especially through the character of Kim. His dynamic mannerisms, cultural association, racial origins etc become points of analysis, sources of the identity crisis that unfolds in the narrative. One can notice him " forgetting his white blood; forgetting even the Great Game as he stooped, Mohammedan fashion" (Kipling, 1978, p. 149) and the Eastern aromas of Lurgan's place makes him "forget he was to be a Sahib" (211), while on the other hand, he tells Hurree "I am a Sahib"(144). Davies' film adaptation recounts such a blurred relationship of the colonizer and the colonized extravagantly and maintains the imperialist tropes. With the blunt depictions of colonizers as harsh, oppressive people like the character of Colonel Creighton, Davies cushions the oppressive features of Kim's character while employing the concept of 'protagonist bias'.

The film ends with the conclusion of 'people being equal' (Davies, 1984, 02:26:53- 02:27:34), excusing all the oppressive misrepresentations like stereotypes, omissions etc, visual indicators like submissive poses of Indians while greeting Europeans, poverty-driven settings etc, inauthentic character representations like using foreign actors to play local Indians etc. Although the plot and dialogues of the Kipling's Kim have clearly been manipulated to fit the postcolonial era, with an increased number of explicit snipes at the British colonial rule like rash British officials (Davies, 1984, 00:48:43- 00:49:31) reflecting the malevolent imperial rule, overthrowing set colonial hierarchies at enlightenment (Davies, 1984, 02:27:00- 02:29:07) etc. Although Kim's identity crisis becomes at its heart, the hybridity of the two-cultures at the 'Third space' as Bhabha describes it, but contradicting the factor of separateness from the pre-existing cultures, Kim's identity revolves as a 'liminality' before fusing with the colonizer, due to his racial identity.

\subsection{Perceptual Orientation of the Audience- From Textual to Visual}

Finally, one can notice how the difference in the medium can affect the perceptual orientation of the narrative. John Berger in his work "Ways of Seeing" says that "Seeing comes before words. The child looks and recognizes before it can speak" (1972), indicating how the visual mode of representing holds many advantages over the text. Visuals are much more impressionable, convey more 
information than words in shorter periods of time, are universal etc, which make it easily preferable over books. Relevant to the current context Berger also mentions the line "“'You painted a naked woman" according to your pleasures and preferences looking at herself in a mirror and name the painting "'Vanity,' thus morally condemning the woman whose nakedness you had depicted for your own pleasure."”' (Berger, 1972, p. 14)

Holding the woman as the subaltern and the male painter as the colonizer we can see the reflection of colonial oppression in the metaphor of nude paintings. The construction of the subaltern, i.e the Orient is dictated by the painter, i.e the colonizer, post which he calls the construction 'an exotic/ savage', having a need for colonial attention which further suggests that the Occidental pleasure in exoticizing the Orient, is what deems it as the savage 'other'(Dissanayake, 1986).

Furthermore, we can notice how the visual text, i.e Davies' film has two major impacts. Firstly, it presents a visualization rather than the imagination of the narrative, introducing new, more apt images of what the author wishes to present rather than the process of creating possible images of the author's intentions from the consumer's collection of memories and ideas. Secondly, one can notice how films are "received perspectives" capable of harbouring biases, opinions, ideals etc. rather than a "direct perspective" which remains a firsthand encounter with the ideas, devoid of any mediator's perspectives. Hence, it can be concluded that films depict a felicitous account of the author's biases, opinions etc and have a greater impact on the consumer's perceptual orientation.

\section{CONCLUSION}

The transformation of the western gaze from the colonial to the Postcolonial period; from a book to a film, brings about numerous consequences of the colonial period to the modern contemporary world which is analysed using various postcolonial and visual culture theories including Bhabha's hybridity, Spivak's homogenisation, Said's Orientalism, Berger's Ways of Seeing and Mulvey's Male Gaze.

Firstly, the analysis implies that the manners of retention, of the colonial oppressive understandings, through western gaze in terms of art and culture in the contemporary times can be comprehended by the way in which Kipling's and Davies' Kim, portrays its settings, characters, use of language and the 'seen-unseen' aspects, in both their works respectively. The forged sense of cultural familiarity evoked through their representation of settings, the use of 'mutual language'; as the hybrid eliminator of the subaltern linguistic identity, the established inferiority of Indic religions as compared to the remarkable and threatened Christianity and the Indian mimicry of the Occidental values become the indicators of imperial oppression.

Secondly, it implies that the construction of the Orient, in terms of the Occidental values are mostly based on homogenisation and binary opposition of the Orient and the Occident, as the former existing as the 'lack of the latter', which strips the subaltern of its identity. Furthermore, the narrative's politics of the colonizercolonized relationship revolves majorly around Kim's identity crisis implying Kim as the physical embodiment of- the hybridity of the two cultures at the 'Third space' as Bhabha describes it but contradicting the factor of separateness from the pre-existing cultures, Kim's identity revolves as a 'liminality' before fusing with the colonizer, due to his racial identity.

Thirdly, it implies that the intricacies of textual and visual means of "perceptual orientation", with regards to the cinematic and textual medium highlight greater and faster orientation with visual media according to Berger's ideas about the Ways of Seeing. It also implied that the construction of the Orient is dictated by the colonizer, post which he calls the construction 'an exotic/ savage', having a need for colonial attention which further suggests that the Occidental pleasure in exoticizing the Orient, is what deems it as the savage 'other'. Furthermore, it can be concluded that visualization and the "received perception" it presents promotes the author's biases, opinions etc better as compared to textual means.

Lastly, it can be noticed how there persists an oppressive 'othering', as an influence and aftermath of the British colonial rule in India, transforming through time and medium in manners of the 'Western gaze', which effectively informs the Occidental construction of the Orient in terms of medium translation, aesthetic codes, textual and visual representation, traditions and institutions in Kipling and Davies' composition of 'Kim'.

This persistence of colonial ideologies from being considered a relic in the past to its residual colonialism virtually pervading the various former colonies, particularly India is an indicator that the decolonization didn't completely rid us of the colonial aftermath. The 'othering' gaze of the Western colonizers continues to haunt the Orient with its misrepresentations and exoticizations, in contemporary times specifically in the manner of art and media. 


\section{REFERENCES}

[1] Ahmad, A. (1992). Orientalism and After: Ambivalence and Cosmopolitan Location in the Work of Edward Said. Economic and Political Weekly, 98-102.

[2] Aljohani, F. M. (2017). Race and Colonization as Seen in Rudyard Kipling's Kim., 6(9), 59-62.

[3] Baker, A. A. (2009). Identity Crisis: Rudyard Kipling's Kim-A Postcolonial Perspective. Epiphany 2.2, 81-103.

[4] Bandyopadhyay, R. (2009). Volunteer tourism and "The White Man's Burden": Globalization of Suffering, White Savior Complex, Religion and Modernity. Journal of Sustainable Tourism, 27-34.

[5] Berger, J. (1972). Ways of seeing. BBC and Penguin, 7-15.

[6] Bhabha, H. K. (2012). The Location of Culture. Routledge.

[7] Columpar, C. (2002). The Gaze as Theoretical Touchstone: The Intersection of Film Studies, Feminist Theory, and Postcolonial Theory. Women's Studies Quarterly 30 1/2, 25 44.

[8] Dissanayake, W. (1986). Exotic Other: Western Representation of India in English literature and film. World Englishes, 5.2(3), 177-187.

[9] Fanon, F. (1967). Black Skin, White Masks. New York: Grove.

[10] Greenblatt, S. (2007). Learning to Curse: Essays in Early Modern Culture. Routledge.

[11] Kipling, R. (1978). Kim. Pan Books Print.

[12] London Films. (1984). Kim .

[13] Loomba, A. (1998). Colonialism/postcolonialism. Routledge.

[14] Mendes, A. C. (2010). Showcasing India Unshining: Film Tourism in Danny Boyle's Slumdog Millionaire. Third Text, 471-479.

[15] Miller, J. H. (1976). Steven's Rock and Criticism as Cure. The Georgia Review, 30(1), 5-31.

[16] Mudambi, A. (2013). Another Look at Orientalism: (An)othering in Slumdog Millionaire. Howard Journal of Communications, 24(3), 275-292.

[17] Mulvey, L. (2009). Visual and other pleasures. Palgrave Macmillan.

[18] Raimbault, E. (2016). Rudyard Kipling's Writing of the Indian Space: The Shifting Lines of Fiction and Reality, Adventure Narrative and Journalism. In Literature and Geography: The Writing of Space throughout History (pp. 250-272). Essay.

[19] Rose, G. (2001). Visual Methodologies: An Introduction to the Interpretation of Visual Materials. Sage, 170-210.

[20] Said, E. (1979). Orientalism. Vintage.

[21] Said, E. (1994). Culture and Imperialism. Knopf: New York.

[22] Spivak, G. C. (2009). Chapter 6: Can the Subaltern Speak. In Geographies of postcolonialism (pp. 27-35). essay, SAGE Publications.

[23] Spurr, D. (2004). The Rhetoric of Empire: Colonial Discourse in journalism, travel writing, and Imperial Administration. Duke University Press.

[24] Thakur, G. B. (2015). Postcolonial Theory and Avatar. Bloomsbury Academic \& Professional.
[25] Yin, J. (2005). Constructing the Other: A Critical Reading of The Joy Luck Club. The Howard Journal of Communications, 16(3), 149-175.

[26] Yoshimoto, M. (1991). The Difficulty of Being Radical: The Discipline of Film Studies and the Postcolonial World Order. Boundary 2, 18(3), 242-257. 